\title{
Electrochemical Reduction of 2-Hydroxyimino-2-phenylacetonitrile. A New Synthetic Route of 2-Phenylglycine from Styrene
}

\author{
Atsutaka KUNAI*, Mitsushige IKEMOTO and Kazuo SASAKI
}

Received January 27, 1990

\section{INTRODUCTION}

2-Phenylglycine ( 1 ) is an important material in synthetic chemistry. Although 2-phenylglycine is synthesized by Strecker method ${ }^{1)}$, this method starts from the expensive material, benzaldehyde. In this paper, we discuss a synthetic route of $2-$ phenylglycine, which starts from a cheaper material, styrene. Since the key step in our route is the conversion of 2-hydroxyimino-2-phenylacetonitrile (2) to 2-amino2-phenylacetonitrile (3), electrochemical reduction is examined in detail.

\section{EXPERTMFNTAL}

\subsection{Preparation of the oxime 2}

\subsubsection{Nitration of styrene}

To a solution of styrene (10 mmol) in dichloromethane $\left(50 \mathrm{~cm}^{3}\right)$, was added $\mathrm{NaNO}_{2}$ (80 mmo1) with stirring. Acetic acid (80 mmo1) was then added over $30 \mathrm{~min}$. After 2 $\mathrm{h}, 6 \% \mathrm{HCl}\left(30 \mathrm{~cm}^{3}\right)$ was added and the solution was stirred overnight. By usual work-up, 4-nitro-3-phenylfurazan 2-oxide (4), mp 100.5-101.5 ${ }^{\circ} \mathrm{C}$; 1it. ${ }^{2)} 100{ }^{\circ} \mathrm{C}$, was obtained $(68 \%)$.

2.1.2 Substitution of nitro group in $\underline{4}$ with azide ion

To a solution of $\mathrm{NaN}_{3}(0.5 \mathrm{mmol})$ in DMSO $\left(2 \mathrm{~cm}^{3}\right)$, was added the oxide 4 ( 0.25 mmol). After $10 \mathrm{~min}$, the solution was poured into a phosphate buffer solution.

Department of Applied Chemistry, Faculty of Engineering, Hiroshima University, Shitami, Saijo, Higashi-Hiroshima 724

Key Words : Phenylglycine from styrene, Reduction of oxime, Aminonitrile
Accepted April 20, 1990

By extraction and subsequent TLC, 4-azido3-phenylfurazan 2 -oxide (5), mp $95{ }^{\circ} \mathrm{C}$, was obtained $(94 \%)$.

\subsubsection{Photolysis of $\underline{5}$}

A solution of the azide $\underline{5}$ ( 1 mol $)$ in dichloromethane-ethanol $\left(7: 3,50 \mathrm{~cm}^{3}\right)$ was irradiated through a Pyrex filter by a 500 W high-pressure mercury 1 amp under a nitrogen atmosphere for $30 \mathrm{~min}$. On $1 \mathrm{y}$ the single isomer, (E)-2-hydroxyimino-2phenylacetonitrile (2), mp $100{ }^{\circ} \mathrm{C}$; lit. 3 ) $97^{\circ} \mathrm{C}$, was obtained (94\%).

\subsection{Synthesis of phenylgiycine from $\underline{2}$}

\subsubsection{Reduction of $\underline{2}$}

Electrochemical reduction was carried out with use of a graphite rod as a cathode and a platinum plate as an anode in an H-shaped electrolytic cell divided with a sintered-glass frit. Base solution was water or a mixture of water and ethanol containing $1 \mathrm{M}\left(\mathrm{M}=\mathrm{mol} \mathrm{dm}^{-3}\right)$ hydrochloric acid. Amounts of the aminonitrile formed were determined by HPLC analysis with use of a Merck Hibar column $(\mathrm{RP}-18)$ as the stationary phase and phosphate solution of $\mathrm{pH} 3.5$ as the eluent.

The oxime $\underline{2}$ ( $1 \mathrm{mmol}$ ) was taken in the cathode compartment of the cell together with $50 \mathrm{~cm}^{3}$ of the base solution and electrolyzed at a current density of 3.5 $\mathrm{mA} \mathrm{cm}{ }^{-2}$. After passing $6 \mathrm{~F} \mathrm{~mol}^{-1}(\mathrm{~F}=96480$ C) of the electricity, the catholyte was condensed in vacuo. The aminonitrile $\underline{3}$ ( $91 \%$ yield by HPLC) was crystallized and isolated by filtration in $87 \%$ yield.

\subsubsection{Hydrolysis of $\underline{3}$ to 2-phenylglycine}

To the catholyte described in the above, 


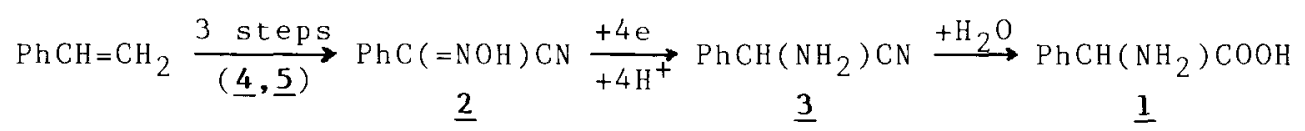

was added conc. HC1 and the solution was heated under reflux for $3 \mathrm{~h}$. 2-Phenylglycine ( $85 \%$ yield by HPLC) was isolated as its hydrochloride salt by filtration from the condensed solution in $44 \%$ yield.

\section{RESULTS AND DISCUSSION}

The starting material, 2-hydroxyimino-2phenylacetonitrile (ㅁ), was easily prepared from styrene. Styrene was converted to 4-nitro-3-phenylfurazan 2-oxide (4 $)$ in $68 \%$ yield. This was further converted to 4-azido-3-phenylfurazan 2-oxide (5) (94\%) and then to the oxime $\underline{2}(94 \%)$.

The electrochemical reduction of the oxime 2 was carried out on the graphite cathode in $1 \mathrm{M}$ aqueous hydrochloric acid until most of the oxime disappeared. The amounts of the aminonitrile formed were monitored by HPLC. Results are exhibited in Fig. 1.

First, the oxime was reduced in water (curve a). When the theoretical amount of the electricity $\left(4 \mathrm{~F} \mathrm{~mol}^{-1}\right)$ was supplied, the aminonitrile was produced in $65 \%$ yield. Further electrolysis up to $8 \mathrm{~F}$ mol $^{-1}$ gave the yield of $89 \%$. Although the chemical yield was excellent in this case, much electricity was necessary for the completion of the reaction. This might be due to the hydrogen evolution which increases gradually with the decrease of the oxime concentration.

We next tried to use $50 \%$ aq. ethanol as the base solution in order to suppress the hydrogen evolution (curve b). In this case, however, the current efficiency (ce) rather decreased.

Improved current efficiency was obtained by the use of $20 \%$ ettanol (curve c). In this case, the aminonitrile formed with $94 \%$ ce at the point of $2 \mathrm{~F} \mathrm{~mol}^{-1}$ of the electrolysis. By passing the theoretical amount of the electricity $\left(4 \mathrm{~F} \mathrm{~mol}{ }^{-1}\right)$, the chemical yield amounted to $82 \%$ ( $82 \%$ ce). After $6 \mathrm{~F} \mathrm{~mol}{ }^{-1}$ of the electrolysis, the

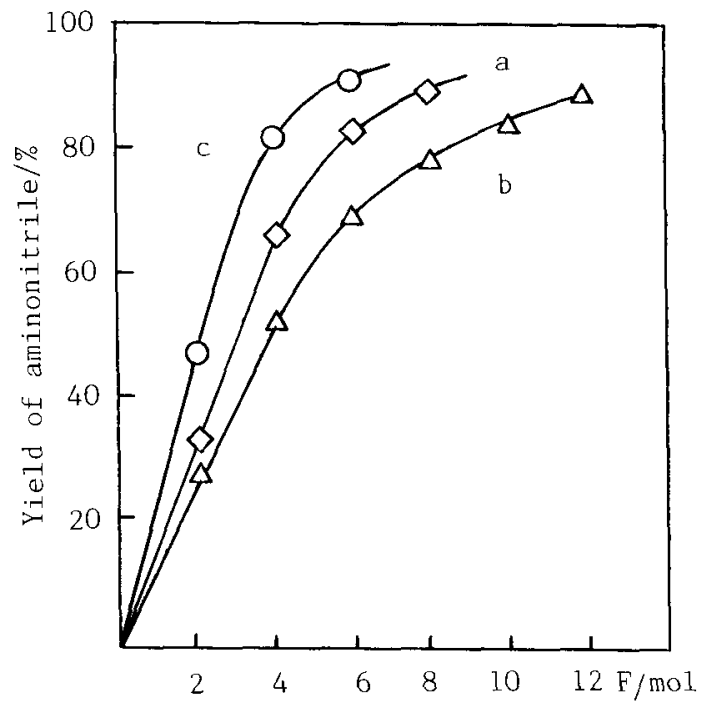

Fig. 1. Reduction of 2. Curves stand for reactions in a: $0 \%, b: 50 \%$, and c: $20 \%$ aqueous ethanol solutions.

aminonitrile was produced in $91 \%$ yield (61\% ce).

The aminonitrile $\underline{3}$ was then hydrolyzed to 2-phenylglycine ( 1 ). The electrolyzed solution containing the aminonitrile $\underline{3}$ was heated for $3 \mathrm{~h}$. The analysis by HPLC showed that 2-phenylglycine was produced in $85 \%$ yield from the oxime $\underline{2}$.

As mentioned above, the electrochemical reduction of the oxime $\underline{2}$ was carried out with good selectivity and current efficiency. Our route may be utilized as a new synthetic method for 2-phenylglycine.

\section{REFERENCES}

1) R.E.Steiger, Org. Syn. Coll. Vol. 3, 84 (1955).

2) a) H.Wieland, Ann. Chem., 328, 154 (1904); b) R.Carbino, V.Mortarini, A. Casco, A.Sanfilippo, and M.L.Ricciardi, Eur. J. Med. Chem. Chim. Therap., 15, 485 (1980); Chem. Abstr., 94, $25636 r$.

3) T.E.Stevens, J. Org. Chem., 32, 670 (1967). 